\title{
Aplikasi Keong Mas (Pomacea canaliculata L.) sebagai Pupuk Organik Cair Pada Pertumbuhan Tanaman Melon (Cucumis melo L) Var. Japonica dan Tacapa
}

\section{Application Of Golden Snail (Pomacea Canaliculata L.) as Liquid Organic Fertilizer On The Growth Of Melon Plants (Cucumis melo L) var. Japonica And Tacapa}

\author{
Vivin Andriani \\ Universitas PGRI Adi Buana, Surabaya, Indonesia \\ Koresponden: vivin.andriani@yahoo.com
}

\begin{abstract}
Abstrak
Keong mas termasuk salah satu organisme yang mengganggu tanaman pada lahan persawahan. Keong mas mengandung senyawa yang dapat digunakan sebagai nutrisi tanaman antara lain asam amino triftofan, Fosfor (P), kalsim (Ca), serta kalium (K), sehingga dapat digunakan sebagai salah satu bahanpupuk organik. Melon (Cucumis melo) merupakan salah satu tanaman buah yang cukup digemari di Indonesia.Penelitian ini bertujuan untuk mengetahui potensi keong mas sebagi pupuk organik cair terhadap pertumbuhan tanaman melon varietas Japonica dan Tacapa. Penelitian ini menggunakan Rancangan Acak Lengkap (RAL) yang terdiri 4 perlakuan 5 ulangan yang terdiridari pupuk organik cair keong mas dengan konsentrasi 0 ppm, 10 ppm, 50 ppm dan kontrol positif (IAA). Parameter yang diamati adalah panjang tanaman, jumlah daun, lebar daun, dan jumlah cabang.Data pengamatan diambil pada 35 hari setelah tanam (HST). Data yang diperoleh dianalisis statistika menggunakan analisis varian satu arah (ANOVA) pada taraf signifikansi 0,05. Hasil analisismenunjukkan bahwa pemberian pupuk organic cair keong mas memberikan pengaruh yang signifikan $(\mathrm{P}<0,05)$ terhadap panjang tanaman, jumlah daun, lebar daun, dan jumlah cabang pada dua varietas melon (Japonica dan tacapa). Berdasarkan hasil yang diperoleh menunjukkan perlakuan pupuk organikcair keong mas 50ppm memberikan hasil yang baik terhadap semua parameter pada 2 varitas melon (japonica, tacapa).
\end{abstract}

Kata Kunci: Keong Mas, Pupuk Organik Cair, Cucumis melo var. Japonica, Tacapa

\begin{abstract}
Golden snail is one of the plants taken from plants in paddy fields. Golden snail contains compounds that can be used as plant nutrients between amino acids triphosphophane, phosphor $(P)$, calcium $(\mathrm{Ca})$, and potassium $(K)$, so that they can be used as an organic fertilizer. Cucumis melo is one of the most popular fruit plants in Indonesia. This study studied the potential of golden snails as organic fertilizer on the growth of Japonica and Tacapa varieties. This study used a RAL consisting of 4 5-repetition settings consisting of liquid organic fertilizer with a composition of $0 \mathrm{ppm}, 10 \mathrm{ppm}, 50 \mathrm{ppm}$ and positive control (IAA). The determining parameters are plant length, number of leaves, leaf width, and number of branches. Observation data were taken 35 days after planting (HST). The data obtained were statistically analyzed using one-way analysis of variance (ANOVA) at a significance level of 0.05. The results of the analysis showed that the golden snail liquid organic fertilizer had a significant effect $(P<0.05)$ on plant length, number of leaves, leaf width, and number of branches in two melon varieties (Japonica and tacapa). Based on the results obtained from 50ppm gold snail liquid fertilizer gave good results on all parameters in 2 varieties of melon (japonica, tacapa).
\end{abstract}

Keywords: Gold snail, liquid organic fertilizer, Cucumis melo var. Japonica, Tacapa

\section{PENDAHULUAN}

Melon (Cucumis melo) merupakan salah satu produk holtikultura yang digemari oleh masyarakat.Citarasa dan aroma buah melon yang menjadi daya tarik masyarakat untuk mengkonsumsinya. Buah ini mengandung 0,6 g protein, $17 \mathrm{mg}$ kalsium, 0,045 $\mathrm{mg}$ thiamine, 
2,4 IU vitamin A, $30 \mathrm{mg}$ vitamin $\mathrm{C}, 0,045 \mathrm{mg}$ vitamin $\mathrm{B}, 0,065 \mathrm{mg}$ vitamin $\mathrm{B} 2,6 \mathrm{mg}$ karbohidrat, $1 \mathrm{mg}$ niasin, 0,065 mg riboflavin, 0,4 $\mathrm{mg}$ zat besi, 0,5 mg nikotin, $93 \mathrm{ml}$ air, dan 0,4 g serat, serta terdapat 23 kalori (Sudjianto dan Veronica, 2009).

Usaha untuk meningkatkan hasil produksi tidak terlepas dari peran pemupukan, oleh karena itu penggunaan pupuk secara instensif harus diperhatikan. Beberapa masalah yang dihadapi dalam budidaya melon adalah pemakain pupuk anorganik yang selama ini digunakan oleh petani dapat memadatkan struktur tanah dan aerasi yang dibutuhkan tanaman (Kuruseng, 2012).

Pupuk organik cair (POC) merupakan suatu jenis pupuk yang berwujud cairan dan memiliki sifat mudah larut pada tanah dan megandung unsure yang berguna bagi tanaman. Kelebihan pupuk cair yanitu mengandung mikroorganisme yang jarang ditemukan pada pupuk organik yang berbentuk padat dan kering (syefani dan lilia dalam Mufida, 2013).

Keong mas dapat dijadikan pupuk karena dapat berfungsi sebagai sumber mikroba yang menguntungkan dalam proses menyuburkan tanah (Suhastyo et al., 2013). Keong mas memiliki kandungan seperti protein, lemak, karbohidrat, Na, K, Riboflavin, Niacin, Mn, C, $\mathrm{Cu}, \mathrm{Zn}$ dan $\mathrm{Ca}$. Selain itu, keong mas mengandung berbagai jenis asam amino dengan komposisi: arginin 18,9\%, histidin 2,8\%, isoleusin 9,2\%, leusin 10\%, lysine 17,5\%, methionin $2 \%$, phenilalamin $7,6 \%$, threonin $8,8 \%$, triptofan $1,2 \%$, dan valin $8,7 \%$ (Damayanti, 2015)

Senyawa asam amino triptofan ini merupakan senyawa prekursor pembentuk POC Indole Acetic Acid (IAA) sehingga dapat dipakai sebagai zat pengatur tumbuh (Chaniago, 2015). Hal ini dapat dijadikan sebagai salah satu alternatif cara untuk mengendalikan hama keong mas di lahan sawah padi. Penelitian ini bertujuan untuk mengetahui potensi keong mas sebagi pupuk organik cair terhadap pertumbuhan tanaman melon varietas Japonica dan Tacapa.

\section{METODE PENELITIAN}

Penelitian dilaksanakan pada bulan Mei sampai Agustus 2019 yang bertempat di Kebun Percobaan Program Studi Biologi Universitas PGRI Adi Buana Surabaya.Alat yang digunakan dalam penelitian ini adalah Total Disolved Solid (TDS), soil tester, $\mathrm{pH}$ meter air, gelas ukur $1000 \mathrm{~mL}$, selang plastik berdiameter $0,5 \mathrm{~m}$, timbangan, polybag ukuran 15 x 15 
cm, ember cat plastik, botol mineral ukuran 1,5 L, saringan, tumbukan, panci, pisau, cetok, pengaduk, lilin/malam, alat tulis dan kamera. Bahan yang digunakan dalam penelitian ini adalah keong mas, gula merah/molase, air cucian beras, EM4, biji melon japonica, biji melon tacapa, tanah, kompos, media tumbuh, air.

\section{Prosedur Kerja}

\section{Pembuatan POC bebahan keong mas Keong mas}

Sebanyak $1 \mathrm{~kg}$ keong mas yang telah di haluskan ditambah 500ml molase, air cucian beras sebanyak 4 liter, dan 160 ml EM4 dimasukkan ke dalam ember. Lalu diaduk sampai homogen.Kemudian menutup ember, mulut ember dilubangi sebagai tempat ujung selang.Ujung selang direkatkan dengan lubang pada mulut ember menggunakan isolasi.

Kemudian ujung selang yang satunya dihubungkan dengan botol mineral berisi air sebanyak setengah botol tersebutuntuk menjaga tekanan udara. Fermentasi dilakukan selama 14 hari. Setelah proses fermentasi selesai, dilakukan penyaringanlarutan hasil fermentasi. Disaring dengan kain planel.Bagian filtrat dikumpulkan dan disimpan pada suhu $4-10^{\circ} \mathrm{C}$ sampai digunakan.

\section{Pelaksanaan}

a. Persemaian biji melon

Biji melon sebelum disemai direndam dalam air selama 1 jam untuk memecahkan dormansi, kemudian disemaikan pada media semai.

b. Penanaman

Penanaman dilakukan setelah bibit berumur 7 hari setelah semai pada media tanam yang terdiri dari media tanam dan kompos.

\section{Tahap Pengambilan Data}

Pengambilan data dilakukan 35 HST dengan mengamati panjang tanaman, jumlah daun, lebar daun dan jumlah cabang.Semua data hasil pengamatan dianalisis statistika menggunakan analisis varian satu arah pada taraf signifikansi 0,05. Uji lanjut untuk mengetahui letak perbedaan antar perlakuan dilakukan dengan menggunakan Uji BNT (Beda Nyata Terkecil) dengan taraf signifikansi 0,05 . 


\section{HASIL DAN PEMBAHASAN}

Hasil pengamatan tinggi tanaman, jumlah daun, lebar daun dan jumlah cabang pada 2 varietas Melon 35 HST secara rinci dapat dilihat pada Table 1. Hasil penelitian memperlihatkan bahwa perlakuan POC Keong Mas berpengaruh signifikan $(\mathrm{P}<0,05)$ terhadap panjang 2 varietas melon.

Tabel 1.Pertumbuhan dua varietas Melon 35 HST

\section{Pertumbuhan}

\begin{tabular}{cccccc} 
Varietas & Konsentrasi & $\begin{array}{c}\text { Panjang } \\
\text { Tanaman }(\mathbf{c m})\end{array}$ & $\begin{array}{c}\text { Jumlah Daun } \\
\text { (helai) }\end{array}$ & $\begin{array}{c}\text { Lebar } \\
\text { Daun }(\mathbf{c m})\end{array}$ & $\begin{array}{c}\text { Jumlah } \\
\text { Cabang }\end{array}$ \\
\hline Japonic & $\mathbf{0}$ & $92,46 \pm 5,58^{\mathrm{e}}$ & $25,67 \pm 2,31^{\mathrm{e}}$ & $5,89 \pm 0,38^{\mathrm{e}}$ & $3,00 \pm 1,00^{\mathrm{d}}$ \\
a & $\mathbf{1 0}$ & $153,69 \pm 4,48^{\mathrm{b}}$ & $26,67 \pm 3,05^{\mathrm{d}}$ & $5,91 \pm 0,12^{\mathrm{e}}$ & $3,33 \pm 0,58^{\mathrm{c}}$ \\
& $\mathbf{5 0}$ & $165,97 \pm 7,11^{\mathrm{a}}$ & $28,00 \pm 2,00^{\mathrm{c}}$ & $7,81 \pm 0,37^{\mathrm{a}}$ & $4,00 \pm 1,00^{\mathrm{b}}$ \\
& $\mathbf{I A A}$ & $167,25 \pm 5.07^{\mathrm{a}}$ & $30,00 \pm 1,00^{\mathrm{b}}$ & $7,68 \pm 0,57^{\mathrm{b}}$ & $3,67 \pm 0,58^{\mathrm{c}}$ \\
\hline Tacapa & $\mathbf{0}$ & $79,31 \pm 2,96^{\mathrm{f}}$ & $26,67 \pm 0,58^{\mathrm{d}}$ & $5,37 \pm 0,53^{\mathrm{f}}$ & $2,33 \pm 0,58^{\mathrm{e}}$ \\
& $\mathbf{1 0}$ & $128,13 \pm 3,10^{\mathrm{d}}$ & $30,67 \pm 0,58^{\mathrm{b}}$ & $5,60 \pm 0,35^{\mathrm{ef}}$ & $3,67 \pm 0,58^{\mathrm{c}}$ \\
& $\mathbf{5 0}$ & $130,34 \pm 1,74^{\mathrm{c}}$ & $26,00 \pm 1,73^{\mathrm{e}}$ & $6,89 \pm 0,41^{\mathrm{d}}$ & $4,33 \pm 0,58^{\mathrm{a}}$ \\
& IAA $^{\mathrm{c}}$ & $130,28 \pm 3,45^{\mathrm{c}}$ & $31,33 \pm 1,53^{\mathrm{a}}$ & $7,20 \pm 0,74^{\mathrm{c}}$ & $4,00 \pm 0,00^{\mathrm{b}}$ \\
\hline
\end{tabular}

Keterangan: Huruf yang berbeda pada kolom dan baris yang sama menunjukkan beda nyata perlakuan pupuk organik cair pada taraf kesalahan $5 \%$.

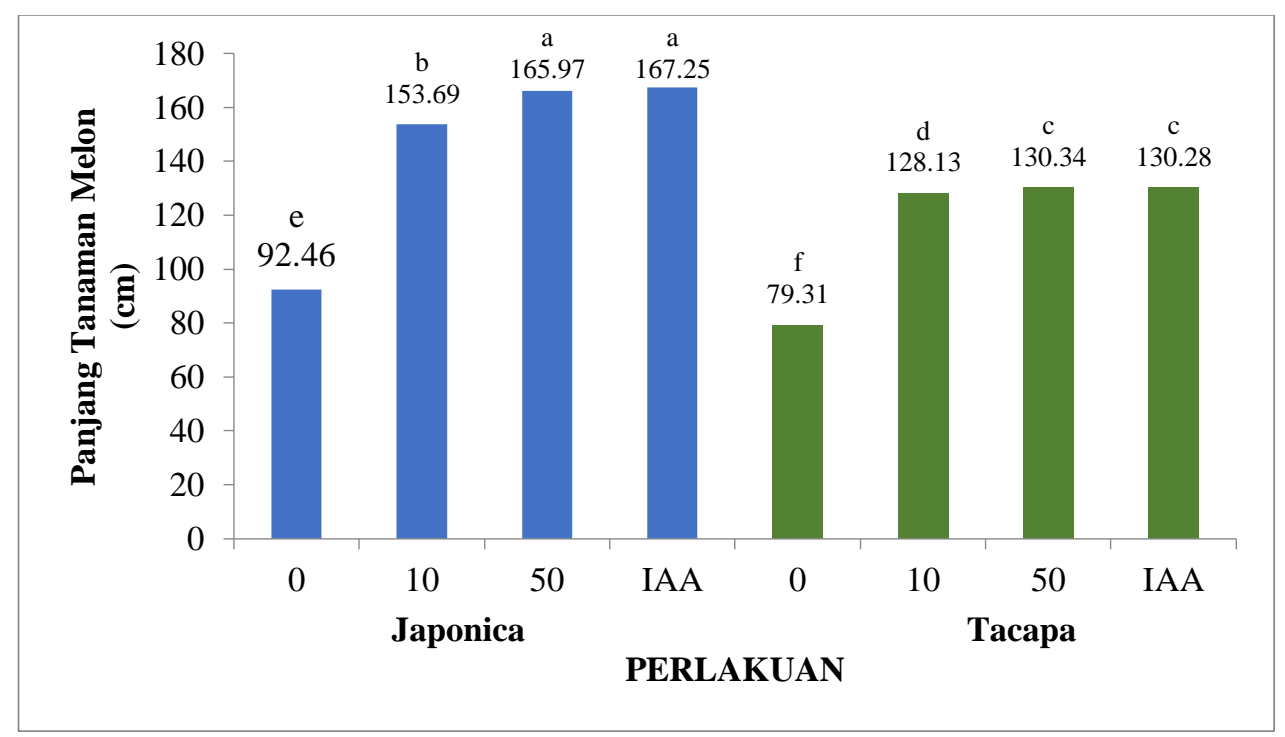

Gambar 1. Panjang tanaman Melon (cm) setelah 35 HST

Gambar 1 menunjukkan bahwa pada varietas japonica kontrol positif (IAA) pajang tanaman tertinggi yaitu $167,25 \pm 5.07 \mathrm{~cm}$, dibandingkan dengan perlakuan POC Keong Mas 50

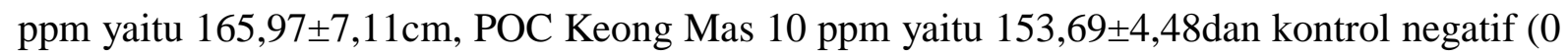
ppm) yaitu $92,46 \pm 5,58 \mathrm{~cm}$. Pada varietas tacapa menunjukkan bahwa pada perlakuan POC 
keong mas 50 ppm panjang tanaman tertinggi yaitu $130,34 \pm 1,74 \mathrm{~cm}$, dibandingkan dengan kontrol positif (IAA) yaitu 130,28 $\pm 3,45 \mathrm{~cm}$, perlakuan POC Keong Mas 10 ppm yaitu $128,13 \pm 3,10 \mathrm{~cm}$ dan kontrol negatif (0 ppm) yaitu 79,31 $\pm 2,96 \mathrm{~cm}$.

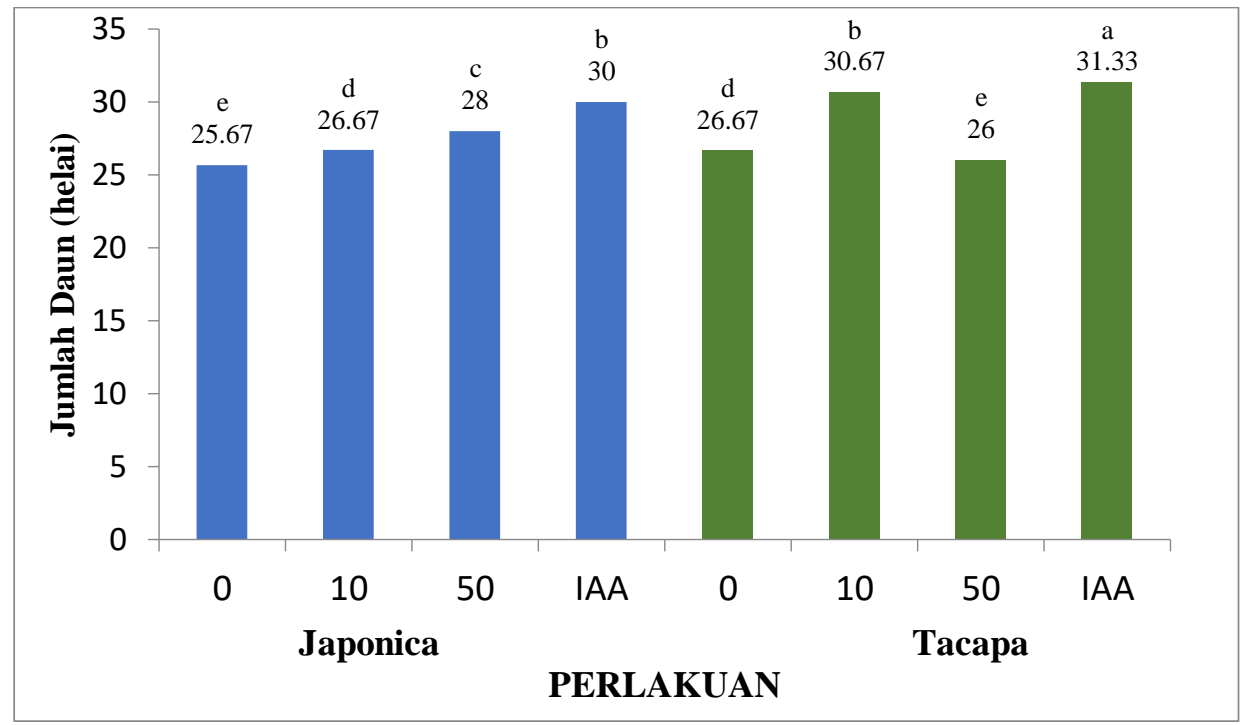

Gambar 2. Jumlah daun (helai) tanaman Melon 35 HST

Hasil penelitian memperlihatkan bahwa perlakuan POC Keong Mas berpengaruh signifikan $(\mathrm{P}<0,05)$ terhadap jumlah daun 2 varietas melon. Pada varietas japonica rata-rata jumlah daun yang tumbuh lebih banyak yaitu pada kontrol positif (IAA) sebanyak $30,00 \pm 1,00$ helai, dibandingkan perlakuan POC Keong Mas 50 ppm sebanyak 28,00 $\pm 2,00$

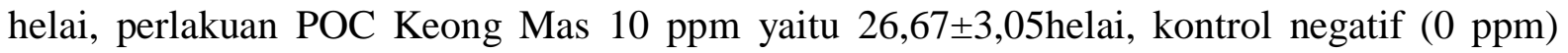
yaitu $25,67 \pm 2,31$ helai.

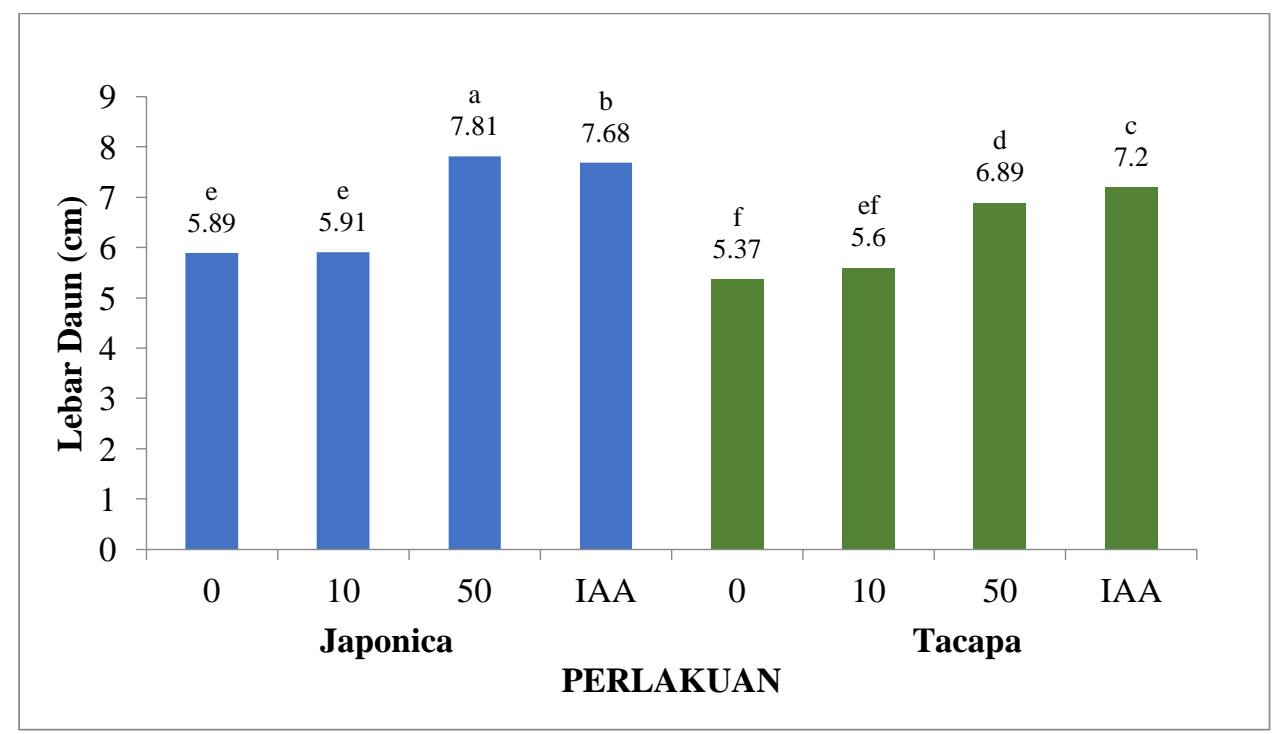

Gambar 3. Lebar daun (cm) tanaman Melon 35 HST 
Pada varietas tacapa rata-rata jumlah daun yang tumbuh lebih banyak yaitu pada kontrol positif (IAA) yaitu 31,33 $\pm 1,53$ helai, dibandingkan pada perlakuan POC Keong Mas 10 ppm yaitu $30,67 \pm 0,58$ helai, perlakuan kontrol negatif ( 0 ppm) yaitu $26,67 \pm 0,58$ helai dan

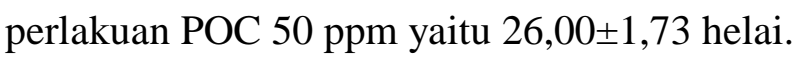

Hasil penelitian memperlihatkan bahwa perlakuan POC Keong Mas berpengaruh signifikan $(\mathrm{P}<0,05)$ terhadap lebar daun 2 varietas Melon. Pada varietas japonica rata-rata lebar daun yang paling lebar yaitu pada perlakuan POC Keong Mas 50 ppm adalah $7,81 \pm 0,37 \mathrm{~cm}$, dibandingkan kontrol positif (IAA) yaitu 7,68 $\pm 0,57 \mathrm{~cm}$, perlakuan POC Keong Mas $10 \mathrm{ppm}$ yaitu $5,91 \pm 0,12 \mathrm{~cm}$, kontrol negatif $(0 \mathrm{ppm})$ yaitu $5,89 \pm 0,38 \mathrm{~cm}$. Pada varietas tacapa rata-rata lebar daun yang paling lebar yaitu pada perlakuan kontrol positif (IAA) yaitu

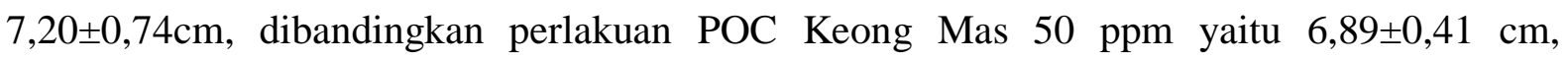

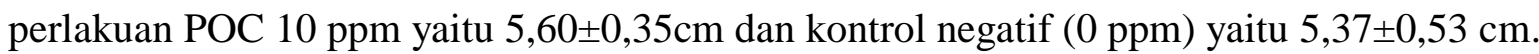

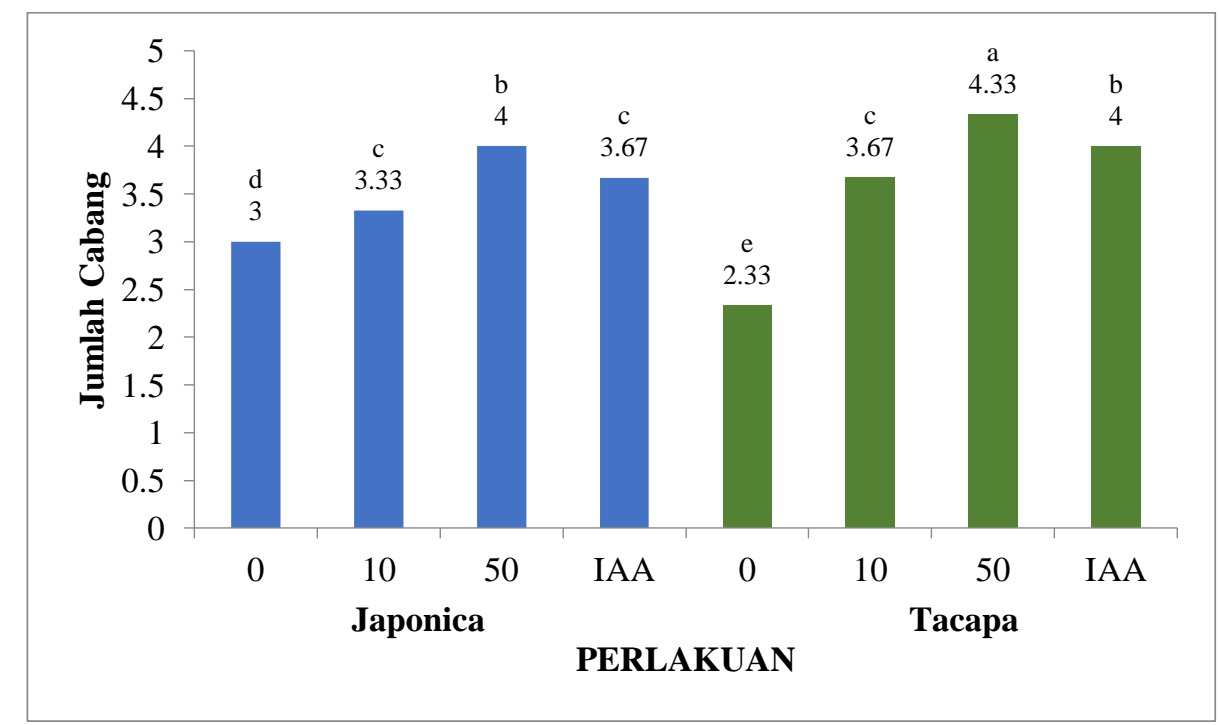

Gambar 4. Jumlah cabang tanaman melon 35 HST

Pada varietas japonica rata-rata jumlah cabang yang paling paling banyak tumbuh yaitu

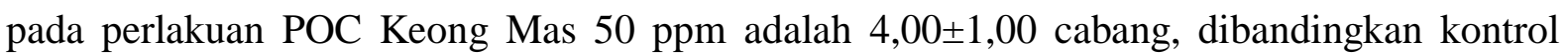

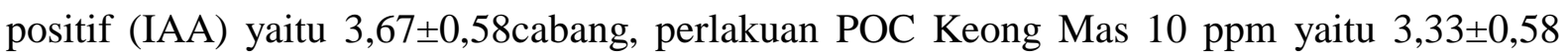

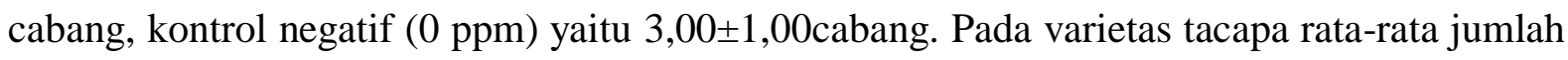
cabang yang paling paling banyak tumbuh yaitu pada perlakuan POC Keong Mas 50 ppm

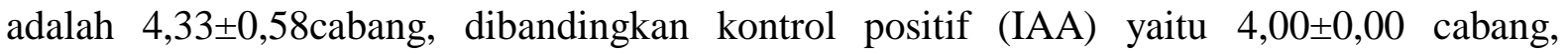




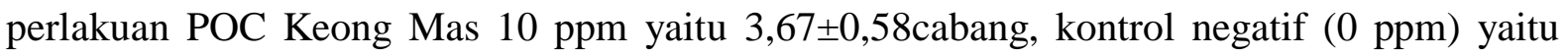
2,33 cabang.

Hasil penelitian yang diperoleh menunjukkan bahwa pemberia POC Keong Mas berpengaru signifikan terhadap panjang tanaman, jumlah daun, lebar daun, dan jumlah cabang. Diduga Keong Mas memiliki senyawa yang dapat membantu pertumbuhan 2 varietas tanaman melon. Hal ini sesuai dengan pernyataan Damayanti (2015) yaitu daging dan cangkang Keong Mas mengandung antara lain lemak, protein, karbohidrat, Natrium, riboflavin, niacin, mangan, kalsium, tembaga, seng dan kalium. Selain itu, keong mas mengandung berbagai jenis asam amino dengan komposisi: arginin 18,9\%, histidin 2,8\%, Isoleusin $9,2 \%$, leusin $10 \%$, lysine $17,5 \%$, methionin $2 \%$, phenilalamin $7,6 \%$, threonin $8,8 \%$, triptofan 1,2\%, dan valin 8,7\%. Menurut Delvita, et al., (2015) cangkang keong mas mengandung kalsium $40,04 \%$ dan fosfor $0,19 \%$.

Daging Keong Mas mengandung salah satu asam aminotriftofan. Asam amino tersebut berperan sebagai prekusor pembentukan Indol Acetic Acid (IAA) yang berperan mendorong pertumbuhan dengan cara pemanjangan sel (Damayanti, 2015). IAA yang di hasilkan oleh Keong Mas akanberperan pada peningkatan pajang dan luas permukaan akar sehingga kemampuan akar akan menyerap nutrisi meningkat (Glick, 2012).

Unsur P pada keong masberperan pada pembentukan protein serta dapat merangsang pertumbuhan tanaman. Fosfor merupakan bagian penyusun nukleoprotein pada inti sel, dimana berperan dalam pengendalian pertumbuhan dan pembelahan sel (Yulipriyanto, 2010). Menurut Munawar (2011) melaporkan bahwa fosfor merupakan unsure yang bersifat esensial pada proses fotosintesis dan metabilosme karbohidrat dimana berfungsi regulator dalam pendistribusian hasil fotosintesis.

Kandungan lain keong mas yaitu kalsium dalam ikatan koloid tanah dapat dibebaskan oleh $2 \mathrm{H}^{+}$. Keberadaan $\mathrm{Ca}^{++}$dalam tanah dapat mencapai 10 kali lipat atau lebih tinggi daripada $\mathrm{K}^{+}$, tetapi penyerapan $\mathrm{K}^{+}$oleh akar tanaman lebih tinggi daripada $\mathrm{Ca}^{++}$. Rendahnya penyerapan $\mathrm{Ca}$, karena $\mathrm{Ca}$ hanya diserap oleh ujung akar muda di mana endodermisnya belum dilapisi suberin, maka penyerapan Ca ditekan oleh adanya $\mathrm{K}^{+}$dan $\mathrm{NH}_{4}{ }^{+}$yang lebih cepat diserap oleh akar (Castan, et al., 2016).Unsur Ca berperan dalam proses fisiologis tanaman dalam peningkatan pembelahan sel, proses diferensiasi pada jaringan serta mepengaruhi proses metabolisme asam nuklet, protein, fenol dan auksin pata tanaman. 
Unsur Ca juga berperan sebagai penyusun ATP dan DNA pada proses metabolisme tumbuhan (Tinto, 2012).

Selain unsure $\mathrm{P}$ dan $\mathrm{Ca}$ Keong Mas juga mengandung unsur kalium yang berperan dalam proses pertumbuhan tanam sesuai dengan pernyataan Wang et al. (2013) bahwa kalium berperan memperkuat ketahanan tanaman dari stress biotik ataupun abiotik. Hal tersebut sependapat dengan penelitian yang dilakuakn Mikkelsen et al. (2012) bahwa kalium di perlukan oleh tanamn kentang dalam jumlah banyak karena digunakan dalam metabolisme. Hasil yang sama di laporkan Ruli (2013) bahwa pupuk K 100 kg memberikan hasil tertinggi terhadap tanaman jagung hibrida varietas Pertiwi-2.

\section{KESIMPULAN}

Dari hasil penelitian dapat disimpulkan bahwa pupuk organik Keong Mas dapat menstimulasi pertumbuhan (panjang tanaman, jumlah daun, lebar daun dan jumlah cabang) pada tanaman Melon. Penelitian ini menyarankan untuk menggunakan konsentrasi yang lebih tinggi dari 50 ppm dan dilakukan uji lanjut pada sistem distribusi nutrien yang ada pada pupuk organik cair Keong Mas pada sel.

\section{REFERENSI}

Castan E, Satti P., González-Polo M., Iglesias M. C., Mazzarino M. J., 2016. Managing the value of composts as organic amendments and fertilizers in sandy soils. Agriculture, Ecosystems and Environment. 224: 29-38.

Chaniago, 2015. Teknik Pembuatan Zat Pengatur Tumbuh (POC) dari Beberapa Mollusca dan Aplikasinya Terhadap Pertumbuhan dan Produksi Tanaman Selada (Lactuca sativa) dengan Hidroponik FHS (Floating Hydroponicc System). Skripsi: Universitas Islam Sumatra Utara.

Damayanti, F. F., 2015. Pngaruh Konsntrasi Mikroorganism Lokal (MOL) Berbahan Dasar Keong Mas (Pomaca canaliculate L.) Terhadap Pertumbuhan Tanaman Cabai Keriting. Skripsi: Universitas Sanata Dharma.

Delvita, H., 2015.Pengaruh Variasi Temperatur Kalsinasi Terhadap Karakteristik Kalsium Karbonat $\left(\mathrm{CaCO}_{3}\right)$ dalam Cangkang Keong Sawah (Pila ampullaceal) Yang Terdapat di Kabupaten Pasaman". Jurnal Pillar Of Physics. Vol. 6: 17-24.

Glick, B. R., 2012. Plant growth-promoting bacteria: mechanisms and applications [ulasan]. Scientifica. 2012:1-15.

Kuruseng, M.A., 2012. Efek residu bokashi terhadap pertumbuhan dan produksi tanaman sawi. Jurnal Agrisistem, Vol. 8(1): 27-35. 
Mikkelsen, R., and Bryan, H., 2012. Fertilizer Management Practice for Potato In the Pacicfic Nortwest. International Plant Nutrition Institute (IPNI). USA.

Mufida, L., 2013. PengaruhPenggunaanKonsentrasi FPE ( Fermented Plant Extrac ) Kulit Pisang Terhadap Jumlah Daun. Kadar Klorofildan Kadar Kalium Pada Tanaman Seledri (Apiumgraveolens). IKIP PGRI Semarang. Semarang. $126 \mathrm{hlm}$.

Munawar, A., 2011.Kesuburan Tanah dan Nutrisi Tanaman. Bogor, IPB Press.

Roli, I., 2013. Respon beberapa varietas tanaman jagung (Zea mays L.) hibrida pada berbagai dosis pupuk kalium terhadap pertumbuhan dan hasil beberapa varietas tanaman jagung (Zea mays L.) hibrida.[Skripsi]. Universitas Gorontalo. Gorontalo.

Sudjianto, U., Veronica, K., 2009. Studi Pemulsaan Dan Dosis NPK Pada Hasil Buah Melon (Cucumis melo L.) Jurnal Sains dan Teknologi. Vol. 2(2): 1-7.

Suhastyo, A. A., Anas I., Santoso, D.A, Lestari, Y., 2013.Jurnal Penelitian. Studi mikrobiologi dan sifat kimia mikroorganisme local (mol) yang digunakan pada budidaya padi metode sri system of rice intensification). Jurnal Sainteks. Volume X.

Tinto, R., 2012. Functions of Boron in Plant Nutrition. https://www.researchgate.net. Diakses 27 Juli 2019.

Wang, X. L., Li, Jia, F. M., and Shi, Y.W.Q., 2013. Increasing PotatoYield with Additional Water and Increased Soil Temperature. Agriculture Water Manage. Vol. 78(4): 181194.

Yulipriyanto, H., 2010. Biologi Tanah dan Strategi Pengelolaannya. Graha Ilmu. Yogyakarta. 